\title{
PELATIHAN PENINGKATAN KOMPETENSI SUPERVISI KEPALA SEKOLAH DAN GURU PAMONG DALAM PENDAMPINGAN PPL MAHASISWA PGSD FKIP UNIVERSITAS MATARAM DI GUGUS 2 KOTA MATARAM
}

\author{
Muh. Irawan Zain*1, Sudirman ${ }^{2}$, Abdul Kadir Jaelani ${ }^{3}$ \\ 1,2,3Program Studi Pendidikan Guru Sekolah Dasar, FKIP, Universitas Mataram \\ *e-mail: irawan_zain@unram.ac.id ${ }^{1}$
}

\begin{abstract}
The purpose of this activity is to provide supervision provisions for school principals and tutors so that tutors in particular are able to provide correct and measurable assistance to PGSD FKIP students who carry out PPL in elementary schools. The problem in this service is the lack of maximum assistance carried out by civil servant teachers to PPL students in Mataram District. The method applied in this counseling is multimethod, namely the lecture method, question and answer method, and demonstration method as well as the assignment method. The training was held at SDN 19 Mataram with a total of 34 teachers. It should be stated that this service was quite successful because $80 \%$ of all participants who were targeted for the training managed to complete the given training tasks. The number of participants who took part in the training was 34 of the 30 people planned, this result was due to the request of the principal from cluster 2 of Mataram District on average asking for additional participants, this means that the implementation of this service has met the previously desired standards.
\end{abstract}

Keywords: supervisory competence, principals, civil servants, $P P L$

\begin{abstract}
Abstrak
Tujuan kegiatan ini adalah memberi bekal supervisi kepada kepala sekolah, dan guru pamong sehingga guru pamong khususnya mampu melakukan pendampingan secara benar dan terukur kepada mahasiswa PGSD FKIP yang melaksanakan PPL di SD. Masalah dalam pengabdian ini adalah kurang maksimalnya pendampingan yang dilakukan oleh guru pamong kepada mahasiswa PPL di Kecamatan Mataram. Metode yang diterapkan dalam penyuluhan ini adalah multi metode yaitu metode ceramah, metode tanya-jawab, dan metode demonstrasi serta metode pemberian tugas. Pelatihan diadakan di SDN 19 Mataram dengan jumlah peserta sebanyak 34 orang guru. Perlu disampaikan bahwa pengabdian ini cukup berhasil karena $80 \%$ dari seluruh peserta yang menjadi sasaran pelatihan berhasil menyelesaikan tugas-tugas latihan yang diberikan. Jumlah peserta yang mengikuti pelatihan adalah 34 orang dari 30 orang yang direncanakan, hasil ini disebabkan karena permintaan kepala sekolah dari gugus 2 Kecamatan Mataram rata-rata meminta tambahan peserta, hal ini berarti bahwa pelaksanaan pengabdian ini telah memenuhi standar yang diinginkan sebelumnya.
\end{abstract}

Kata kunci: kompetensi supervisi, kepala sekolah, guru pamong, PPL

\section{PENDAHULUAN}

Guru adalah pendidik profesional. Menurut UU No. 14 Tahun 2005, pasal 1 ayat 1, Guru adalah pendidik profesional dengan tugas utama mendidik, mengajar, membimbing, mengarahkan, melatih, menilai, dan mengevaluasi peserta didik pada pendidikan anak usia dini jalur pendidikan formal, pendidikan dasar, dan pendidikan menengah. Begitu pentingnya kedudukan guru, maka kompetensi calon guru perlu dipersiapkan sebaik mungkin. Pada ayat 10, kompetensi adalah seperangkat pengetahuan, keterampilan, dan perilaku yang harus dimiliki, dihayati, dan dikuasai oleh guru atau dosen dalam melaksanakan tugas keprofesionalan. Selanjutnya pada pasal 2 ayat 1, guru mempunyai kedudukan sebagai tenaga profesional pada jenjang pendidikan dasar. Dengan kedudukan dan fungsi yang strategis ini calon guru SD perlu dipersiapkan sedemikian rupa agar dapat mendidik, mengajar, membimbing, menilai dan mengevaluasi peserta didiknya dengan benar. 
PGSD sebagai salah satu Program Studi di FKIP diharapkan mampu mempersiapkan calon guru SD yang memiliki kompetensi dan kualifikasi profesioanalitas. PPL merupakan salah satu dari matakuliah yang harus ditempuh mahasiswa PGSD untuk memenuhi kualifikasi tersebut. Agar pelaksanaan PPL di SD dapat berjalan sesuai yang distandarkan, maka diperlukan pembimbing PPL yang mumpuni. Kepala sekolah dan guru pamong selaku pembimbing langsung di tingkat sekolah setidaknya memiliki kompetensi yang dipersyaratkan. Dalam UU No. 14 Tahun 2005 dinyatakan kompetensi yang harus dimiliki guru adalah kompetensi profesional, kompetensi paedagogis, kompetensi sosial, dan kompetensi kepribadian.

Hasil obervasi lapangan di beberapa SD, yaitu di SDN yang menjadi tempat pelaksanaan PPL mahasiswa PGSD khususnya SD se Kecamatan Mataram, yang terdiri 5 gugus, dan masingmasing gugus terdapat 5-6 SD. Selain memperoleh banyak pengalaman ketika PPL, adapula beberapa keluhan mahasiswa, yaitu: (1) pada kegiatan mengajar terbimbing, banyak yang tidak mengacu kepada format penilaian yang distandarkan fakultas (Unit PPL), untuk SD yang menggunakan KTSP-2006, pembimbingan sering tidak terfokus pada turunan SK-KD-Indikator dan skenario pembelajaran; dan untuk K-13, pembimbingan tidak terfokus pada turunan KDIndikator dan penilaian; (2) belum maksimalnya bimbingan ketika mengajar mandiri, mahasiswa terkesan dilepas mengajar dan sebagai sebuah rutinitas; (3) Sering menjadi guru pengganti ketika guru kelas berhalangan hadir, sehingga mengajar terkesan seadanya karena tidak ada RPP; (4) pekerjaan administrasi lebih sering menjadi prioritas, seperti pengaturan buku perpustakaan, membantu mengisi nilai siswa, dan hal-hal sejenisnya; dan (5) Mahasiswa tidak selalu diberikan ijin konsultasi di pagi hari ke dosen pembimbing skripsi, sehingga terpaksa konsultasi dilakukan sore hari. Akibatnya, penyelesaian studi akhir menjadi molor.

Walaupun data di atas merupakan hasil wawancara dengan mahasiswa dan guru pamong terutama ketika dosen melakukan bimbingan, tetapi paling tidak informasi di atas dapat dijadikan acuan untuk segera dicari alternatif jalan keluarnya. Wiles (Imron: 2011:8) berpendapat bahwa supervisi pembelajaran adalah: 1) serangkaian bantuan yang berwujud layanan profesional; 2) layanan profesional tersebut diberikan oleh orang yang lebih ahli kepada guru; dan 3) maksud layanan tersebut adalah agar dapat meningkatkan kualitas proses dan hasil belajar sehingga tujuan pendidikan yang direncanakan dapat dicapai. Pendapat Wiles di atas menunjukkan bahwa jalan keluar yang paling mungkin dan segera dapat dilakukan adalah melakukan pengabdian kepada masyarakat kepada kepala sekolah dan guru pamong.

Tujuan kegiatan ini adalah memberi bekal supervisi kepada kepala sekolah, dan guru pamong sehingga guru pamong khususnya mampu melakukan pendampingan secara benar dan terukur kepada mahasiswa PGSD FKIP yang melaksanakan PPL di SD. Manfaat kegiatan ini adalah memberikan bekal supervisi kepada para kepala sekolah khususnya dalam menentukan kriteria guru yang tepat sebagai guru pamong, dan menyampikan kepada guru pamong tentang hal-hal yang bersifat teoritis dan teknis dalam melakukan pendampingan kepada mahasiswa PPL.

\section{METODE}

Metode yang diterapkan dalam penyuluhan ini adalah multi metode yaitu metode ceramah, metode tanya-jawab, dan metode demonstrasi serta metode pemberian tugas. Metode ceramah diterapkan saat penyampaian materi penyuluhan, dan metode tanya-jawab serta demonstrasi diterapkan dalam rangka memperdalam pemahaman peserta terhadap materi yang telah sampaikan. Metode pemberian tugas dan diskusi diberikan untuk melatih guru dalam merancang skenario pembelajaran, menentukan strategi pembelajaran, merancang kegiatan pembelajaran; dan merancang evaluasi hasil belajar. (1) menetapkan jumlah peserta pelatihan yaitu guru-guru SD Gugus 2 se Kecamatan Mataram yang terdiri dari 5 sekolah dengan mengirim masing-masing guru sebanyak 7 orang; (2) pelatihan diadakan di SDN 19 Mataram dengan jumlah peserta sebanyak 34 orang guru; (3) ceramah penyampaian materi pelatihan tentang konsep mengajar dan supervisi pembelajaran; (4) tanya-jawab dan diskusi tentang materi pelatihan tentang konsep mengajar dan supervisi pembelajaran; (5) simulasi pendampingan RPP 
pembelajaran pada mahasiswa PPL S1 PGSD secara berkelompok; (6) simulasi penyusunan rundown pelaksanaan PPL terbimbing, mandiri dan evaluasi; \& (7) melakukan refleksi kegiatan oleh tim pengabdian.

\section{HASIL DAN PEMBAHASAN}

Pengabdian dilaksanakan di SDN 24 Mataram. Peserta terdiri atas 34 guru dari gugus 2 Kota Mataram. Peserta dikumpulkkan di satu titik yaitu aula SDN 24 Mataram secara tatap muka pada tanggal 24 Agustus 2018.

Materi terdiri atas tiga pokok utama tentang supervisi oleh Kepala Sekolah dan Guru Pamong yaitu : (1) supervisi akademik; (2) supervisi pembelajaran; dan (3) supervisi klinis. Materi pertama disampaikan oleh bapak Muh. Irawan Zain, M.Pd. Materi Kedua disampaikan oleh Bapak Abdul Kadir Jaelani, M.Pd. Materi ketiga disampaikan oleh bapak Dr. H. Sudirman, M.Pd.

Guna mengetahui efktivitas kegiatan pengabdian, dilakukan pretest dan postes selama kkegiatan berlangsung. Pada tahap awal sebanyak 24 guru masih mengalami kendala dalam pemahaman konsep dan teori, serta aplikasi supervisi pendidikan. Kebanyakan guru dan kepala sekolah jarang mengetahu konsep teori supervisi, apalagi dalam pelaksanannya.

Namun setelah dilakukan penyampaian materi sebanyak 80\% dari seluruh peserta yang menjadi sasaran pelatihan berhasil menyelesaikan tugas-tugas latihan yang diberikan. Jumlah peserta yang mengikuti pelatihan adalah 34 orang dari 30 orang yang direncanakan, hasil ini disebabkan karena permintaan kepala sekolah dari gugus 2 Kecamatan Mataram rata-rata meminta tambahan peserta, hal ini berarti bahwa pelaksanaan pengabdian ini telah memenuhi standar yang diinginkan sebelumnya.

Ada tiga tahapan pelaksanaan pengabdian, yaitu: pertama, Penerapan metode ceramah dan diskusi dilakukan untuk menyampaikan konsep mengajar dan supervisi pembelajaran. Penyampaikan materi ini berlangsung selama satu kali pertemuan oleh tim pengabdian. Penyampaian materi tentang konsep mengajar yang dilakukan guru berisi tentang pendidikan dan profesi guru serta supervisi kepala sekolah (langkah-langkahnya).

Tahap kedua yaitu diskusi dan simulasi pendampingan yang dimulai dari merancang pembelajaran, menentukan strategi pembelajaran, merancang kegiatan pembelajaran; dan merancang evaluasi hasil belajar. Dalam diskusi tersebut, hal yang paling menjadi diskusi mendalam adalah turunan KD menjadi indikator. Hal ini disebabkan karena di Kurikulum Tahun 2013 tidak ada indikator sementara tuntutan terhadap evaluasi hasil proses pembelajaran harus diadakan. RPP yang digunkan untuk diskusi adalah 13 RPP mengajar terbimbing mahasiswa yang sedang mengikuti PPL saat ini. Ke-13 RPP tersebut didiskusikan secara berkelompok dengan anggota masing-masing 3 orang per kelompok.

Kegiatan ketiga yaitu imulasi menyusun rundown kegiatan pendampingan kepada mahasiswa PPL yang dimulai dari mengajar terbimbing, mengajar mandiri, dan evaluasi. Penyusunan jadwal mengajar yang disesuaikan dengan jadwal mengajar guru dan mahasiswa menyita waktu cukup lama terutama di RPP terbimbing, kesulitannya adalah membagi waktu konsultasi dengan jam mengajar guru, karena selain konsultasi dengan guru mahasiswa juga diharuskan konsultasi dengan dosen.

Dari refleksi pelaksanaan kegiatan, ditemukan beberapa hal yang menjadi pertimbangan yaitu penyusunan run-down tetap menguntungkan kedua belah pihak agar pendampingan mahasiswa PPL S1 PGSD dapat berjalan sesuai standar yang diharapkan.

Hambatan utama dalam kegiatan pengabdian ini yaitu pemahaman awal guru da kepala sekolah yang cukup kurang dalam hal konep dan teori supervisi sehingga awalnya peserta banyak mengalami kesulitan. Namun karena kemauan belajar dan motivasi dari tim pengabdian, serta pelaksanaan workshop berbasis praktik maka terjadi peningkatan pemahaman baik secara teori maupun praktik supervisi oleh kepala sekolah dan guru pamong. Diharpkan pemahaman ini juga 
berdampak pada peningkatan kompetensi mahasiswa PPL FKIP Universitas Mataram karena dibimbing dan disupervisi oleh kepala sekolah dan guru yang mumpuni.

\section{KESIMPULAN}

Dari kegiatan pengabdian pada masyarakat yang dilaksanakan di SDN se Kecamatan Mataram dapat disimpulkan bahwa peserta memperoleh pengalaman yang cukup selama pelatihan untuk dapat melakukan pendampingan pada mahasiswa PPL S1 PGSD, mulai dari pendampingan penyusunan RPP khususnya penyusunan indikator, merancang kegiatan pembelajaran; dan merancang evaluasi hasil belajar, dengan tahapan sebagai berikut:

1. Penyampaian materi tentang pendidikan dan profesi guru serta supervisi kepala sekolah oleh tim pengabdian. Berikutnya adalah diskusi mendalam tentang turunan KD menjadi indikator. Hal ini disebabkan karena di Kurikulum Tahun 2013 tidak ada indikator sementara tuntutan terhadap evaluasi hasil proses pembelajaran harus diadakan sehingga RPP yang digunakan untuk diskusi adalah RPP KTSP dan RPP Kurikulum 2013 berjumlah 13 RPP yang didiskusikan secara berkelompok dengan anggota masing-masing 3 orang per kelompok.

2. Simulasi menyusun rundown kegiatan pendampingan kepada mahasiswa PPL dimulai dari mengajar terbimbing, mengajar mandiri, dan evaluasi. Dalam diskusi, penyusunan run-down kegiatan mengajar guru dengan mahasiswa PPL menyita waktu cukup lama terutama di RPP terbimbing, kesulitannya adalah membagi waktu konsultasi dengan jam mengajar guru, karena selain konsultasi dengan guru mahasiswa juga diharuskan konsultasi dengan dosen. Kemudian hasil refleksi kegiatan, ditemukan beberapa hal yang menjadi pertimbangan yaitu penyusunan run-down mempertimbangkan dapat menguntungkan kedua belah pihak.

\section{DAFTAR PUSTAKA}

FKIP. (2017). Buku Pedoman PPL FKIP Universitas Mataram. Arga Fuji. Mataram

Imron, Ali. (2011). Supervisi Pembelajaran Tingkat Satuan Pendidikan. Bumi Aksara. Jakarta.

Sudjana, Nana. (1988). Dasar-dasar Proses Belajar Mengajar. Bandung: Sinar Baru.

Sahertian, P.A. (2000). Konsep Dasar dan Teknik Supervisi Pendidikan dalam Rangka Pengembangan Sumber Daya Manusia. Jakarta: Rineka Cipta.

Sutisna, Oteng. (1993). Administrasi Pendidikan: Dasar Teoritis untuk Praktek Profesional. Bandung: Angkasa.

Satori, Djam'an. (1989). Pengembangan Model Supervisi Sekolah Dasar (Penelitian terhadap Efektivirtas Sistem Pelayanan/Bantuan Profesional bagi Guru-guru SD di Cianjur Jawa Barat). Disertasi Doktor pada PPS IKIP Bandung: tidak diterbitkan.

Sulo, Sulu Lipu La. (1998). Supervisi Klinis Pendekatan Bimbingan dalam Penyelenggaraan Program Pengalaman Lapangan (PPL). Jakarta: Depdikbud Dirjen Dikti PPGSM.

UU-RI Nomor 14 Tahun 2005. Sisdikker.dikti.go.id. Diakses tahun 2017.

Winardi. (1996). Manajemen Supervisi. Bandung: Mandar Maju. 